\title{
EFFECT OF IRRIGATION INTERVALS, FERTILIZER LEVELS AND PLANTING METHODS ON YIELD AND WATER USE EFFICIENCY
}

\author{
El-Sharkawey, Amal, F.*
}

\section{ABSTRACT}

This work was carried out during summer and winter seasons at Gharbia Governorate, to study the effect of irrigation intervals ( every14, 21 and28 day ),fertilizer levels (40,50 and 60uN/ fed), planting methods (row and two rows) and interaction between them on irrigation water quantity, total yield and water use efficiency of okra and garlic crops . Data show that decreasing when irrigation intervals increase from every 14 days to every 21 and with a bout 5.89 and $17.50 \%$ for okra and about 11.60 and $25.27 \%$ for garlic respectively.

Meanwhile irrigation water quantity increases by increasing fertilizer levels from 40 to 50 and $60 \mathrm{uN} /$ fed by $8.60,15.66 \%$ for okra and about ,5.00 and $11 \%$ for garlic respectively.

Planting on two rows save irrigation water quantity by 12.09 and 14.54 $\%$ for okra and garlic crops respectively compering by planting on one row .Increasing irrigation intervals decrease the yield of okra by 6.00 and $9.8 \%$ but increase the garlic by about 8.73 and $18.59 \%$ for irrigation every 21 and 28 day compering by irrigation every 14 days . Also, data show that increasing fertilizer levels from 40 to 50 and $60 \mathrm{uN} /$ fed increase the okra yield by 9.06 and $18.53 \%$ respectivily for 50 and 60 $u N /$ fed compered by40 uN /fed of okra crop. The same trend was happened for the garlic yield but increasing percent was about 6.40 and 7.73 \%respectively.

Water use efficiency affected by irrigation intervals, fertilizer levels, planting methods and interaction between them .

Increasing irrigation intervals to 2land 28 days compered by irrigation every 14 day decrease the WUE by about 6.3 and $18 \%$,resp. for okra crop. . While for garlic crop, increasing irrigation intervals increase WUE by 13.3 and $16.53 \%$, resp.

\footnotetext{
*Sen. Res., Ag. Eng. Res. Instit.,Dokki, Giza,
} 
Moreover increasing fertilizer levels, increased WUE by 3.06 and $4.37 \%$ for okra and 2.47 and $3.73 \%$ for garlic under 50 and $60 \mathrm{uN} / \mathrm{fed}$ compared with $40 \mathrm{uN} /$ fed resp.

The same trend happen in planting methods. Using two rows increased the WUE by 17.59 and $25.67 \%$ for okra and garlic crops, resp. .

\section{INTRODUCTION}

The economic importance of Garlic and okra has recently increased because its production exceeds the domestic

1 consumption, and hence the country becomes able to export large quantities to Arab countries . Very little researches have been conducted to evaluate the effect of irrigation water quantity, fertilizer levels and cultural practices on the growth, yield of okra and garlic and Water Use Efficiency(WUE). Fertilization and use of chemicals are major problems under different irrigation intervals in old lands in all cases .

Okra (Abelmoschusesculentus) belongs to the family of Malvaceae is one of the important vegetable crops grown throughout the tropical and warm temperature regions of the world. Globally, okra is cultivated in an area of 0.78 million ha producing 4.99 million MT with an average yield of 6.39 t ha-1 (Thanavendan and Jeyarani, 2009). Okra is one of the most popular fruit vegetables grown in wet, and dry zone. The total area under okra cultivation is reported to be 7066 ha producing average yield of $5.3 \mathrm{t}$ ha- 1 thus the total annual okra production in Sri Lanka is 37,330 MT with a per capita availability of $2.0 \mathrm{~kg}$ ha-1 (Department of Agriculture, 2010). A water shortage due to limited groundwater and surface water resources in Jaffna Peninsula has become a major concern in the development of irrigated agriculture (Rajasooriyar et al., 2002). Increasing water use efficiency by using improved irrigation techniques is a priority for the agricultural sector.

Home et al ( 2002 ) reported that, production of fresh vegetables usually calls for application of large amounts of irrigation water and fertilizer nitrogen $(\mathrm{N})$. Combined application of high rates of water and $\mathrm{N}$ leads to excessive leaching of nitrate nitrogen, making most of it unavailable to the plants. Very few studies have been conducted to investigate the combined effect of irrigation method and scheduling on the yield, $\mathrm{N}$ use 
(based on $\mathrm{N}$ balance in the root zone) and $\mathrm{N}$ uptake (based on $\mathrm{N}$ content of plant material) of vegetable crops, especially Okra.

Garlic (Allium sativum L.) belongs to the familyof Alliaceae (Hanelt, 1990). Garlic originated in central Asia and later spread to Mediterranean region (Simon, 2001, Kilgori et al., 2005). It is grown in both temperate and tropical climates (FAO, 2001). Because of its commercial value, garlic is one of the most promising vegetable cultivated in the northern part of Nigeria during the dry season, under irrigation. At this particular time, most vegetable crops cannot be grown through to maturity successfully without adequate watering

Hanson, et al ( 2003 ) Said that the effect amount of applied water on garlic yield was investigated. Irrigation per week, one irrigation every 1.5 weeks, and one irrigation every 2 weeks. were used to develop relationships between garlic yield and applied water on sandy loam and clay loam. The highest yield occurred for the one irrigation per week treatment of the irrigation frequency experiment. Garlic yield decreased linearly with applied water in sandy loam. The limited amount of stored soil-moisture in the sandy soil was insufficient to compensate for deficit irrigation. These results suggest that on sandy soil, weekly irrigations of an amount equal to the crop evapotranspiration plus losses due to irrigation inefficiencies should be applied. Mikko et al. (2000) Reported positive effects of frequent irrigation on yield attributes of garlic. He reported 5 days irrigation interval as being optimum, probably as a result of differences in soil type and climate. Also Buwalda (1987) reported that garlic crop did not withstand application of excess water and that water stress could decrease both growth and yield attributes by up to $60 \%$. Ahmed et . al ( 2007 ) Studied performance of garlic . (Allium sativum) to varying levels of irrigation interval and clove size. The results obtained revealed that 3-day irrigation interval significantly affected number of leaves per plant, plant height at maturity, bulb yield, bulb weight, number of leaves per plant, plant height at maturity, bulb yield, bulb weight, number of cloves per bulb and clove weight throughout the period of investigation, while increase in the number of days between irrigation interval negatively affected the growth and yield and 
performance of the garlic. It was concluded from this study that large clove size and applying irrigation at 3-day interval may be recommended for good performance of garlic

Ali et al ( 2010 ) reported that the yield and water use efficiency of garlic responses to the irrigation system, intra-row spacing and nitrogen fertilization. Results revealed that produced yield by two irrigation systems were approximately similar $\left(13,045 \mathrm{~kg} \mathrm{ha}^{-1}\right)$ in two cropping years. In addition, with varying intra-row spacing from 12 to $8 \mathrm{~cm}$, the yield was increased by $23 \%$. Application of 60 and $120 \mathrm{~kg} \mathrm{ha}^{-1}$ fertilizer for plant with space of $8 \mathrm{~cm}$ produced the highest yield and application of 60 and $120 \mathrm{~kg} \mathrm{ha}^{-1}$ fertilizer for space of $12 \mathrm{~cm}$ produced the lowest yield. obtained WUE by furrow system averaged $2.7 \mathrm{~kg} \mathrm{~m}^{-3}$.

The main aim of this study is to achieve the effect of water irrigation quantity according to irrigation intervals. Fertilizer levels and planting methods on yield and water use efficiency for okra and garlic .

\section{MATERIALS AND METHODS}

Two field experiments were executed during summer and winter seasons in Gharbia governorate, to study the effect of three irrigation intervals ( 14,21 and 28 days ), three levels of fertilizer ( 40 , 50, and $60 \mathrm{u} \mathrm{N} /$ fed )and two planting methods( row and two rows ) on growth, yield, water use efficiency and quality of okra and garlic crops and water utilization as well. The soil texture of the experimental site is classified as clay soil, as shown in Table (1)

Table (1) : Mechanical analysis and some soil moisture contents of the studied soil experimental.

\begin{tabular}{|l|l|l|l|l|l|l|l|}
\hline $\begin{array}{c}\text { Depth } \\
\text { cm }\end{array}$ & $\begin{array}{c}\text { Fine } \\
\text { sand } \%\end{array}$ & $\begin{array}{c}\text { Coarse } \\
\text { sand\% }\end{array}$ & Silt\% & Clay\% & $\begin{array}{c}\text { Soil } \\
\text { texture }\end{array}$ & F C.\% & W.P\% \\
\hline $0-15$ & 3.65 & 20.35 & 26.4 & 49.6 & Clay & 42.40 & 21.20 \\
\hline $15-30$ & 3.55 & 20.60 & 27.45 & 48.40 & Clay & 42.80 & 20.60 \\
\hline $30-45$ & 3.60 & 20.60 & 28.30 & 47.50 & Clay & 43.70 & 21.80 \\
\hline $45-60$ & 4.20 & 20.80 & 28.40 & 46.60 & Clay & 44.00 & 22.20 \\
\hline
\end{tabular}

Growth and yield as influenced by some irrigation intervals in old valley. Seeds were sow of okra on 10 April and harvested on October 
and Garlic in Nov. and harvested in April The experimental design was split split - plot design with three replications.

Main - plot (irrigation intervals)

1 - irrigation every 14 day ( I1)

2 - irrigation every 21 day

3 - irrigation every 28 day

Sub main - plot (fertilizer levels )

$1-40 \mathrm{u} \mathrm{N} / \mathrm{fed}(\mathrm{F} 1)$

$2-50 \mathrm{uN} /$ fed (F2)

3-60 u N/ fed (F3)

Sub sub main plot ( planting methods )

1- one row $(\mathrm{R})$

2- two rows (2R)

-Irrigation water calculations:

Irrigation water was delivered to the plots through a circular orifice and water quantity was measured using the formula of immersed orifice according to James(1988).

$$
\mathrm{Q}=0.61 \mathrm{~K} \mathrm{AH}^{0.5}
$$

Where:

$\mathrm{Q}=$ Orifice discharge $\mathrm{L} / \mathrm{sec}$.

$\mathrm{A}=$ the area of orifice opening $\left(\mathrm{cm}^{2}\right)$

$\mathrm{H}=$ Effective water head over the orifice center (m.)

$\mathrm{K}=$ Unit constant $\left(\mathrm{K}=0.443\right.$ for $\mathrm{Q}$ in $\mathrm{L} / \mathrm{sec}, \mathrm{A}$ in $\mathrm{cm}^{2}$, and $\mathrm{H}$ in $\mathrm{m}$ )

-Moisture content:

Water holding capacity (W.H.C) $\mathrm{mm}$ was calculated by using following equation,

W.H.C $=($ FC $\%-$ PWP $\%) \times$ bulk density $\times$ root zone, $\mathrm{m} \times 10$

where:

FC is field capacity, \%.

PWP is permanent wilting point, $\%$.

Maximum net water requirement (Max - n.w .r ) mm.

Max. n.w. $r=$ MAD $\times$ W.H.C $\div 100$.

M A D =Moisture available deficit $\mathrm{mm} / \mathrm{m}$. 
Maximum gross water requirement ( $\max -$ g.w.r ), mm

Max-g.w.r. $=$ max-n.w.r. $\times 100 \div \mathrm{AE}$

Yield:

At harvest yield of selected crops, determined from the field and computed the weight of fruit yield (ton / fed.)

4-Water Use Efficiency (WUE):

Water use efficiency for crop is the weight of the yield produced per volume unit of applied water expressed as cubic meters of water (Michael, 1978).

\section{RESULTS AND DISCUSSION}

\section{1-Irrigation water quantity.}

Irrigation water quantity for garlic and okra affected by irrigation intervals, fertilizer levels, planting methods and interaction between them.

Data in Table ( 2 ) reveal that, when irrigation intervals increase irrigation water quantity decrease in both okra and garlic crops, the decreasing percentage were $5.89,17.50 \%$ of okra and $11.60,25.27 \%$ of garlic when irrigation every 21 and 28days compared with 14 days. This result due to decrease the numbers of irrigations.

Nerveless data show that, irrigation water quantity increase by increasing fertilizer levels , by $8.60,15.66 \%$ for okra and 5.08 and $10.96 \%$ for garlic under fertilizer $50 \& 60 \mathrm{uN} /$ fed compared with $40 \mathrm{u} \mathrm{N} / \mathrm{fed}$, respectively.

Data in table ( 2 ) show that, planting methods effect on irrigation water quantity . Planting on two rows save irrigation water quantity by 12.09 and $14.54 \%$ compered by one row of okra and garlic crops, respectively. Table (2) : Irrigation water quantity affected by irrigation intervals , fertilizer levels and planting methods .

\begin{tabular}{|l|c|c|c|c|c|c|c|c|}
\hline \multirow{3}{*}{$\begin{array}{l}\text { Treatm } \\
\text { ents }\end{array}$} & \multicolumn{9}{|c|}{ Irrigation water cm } \\
\cline { 2 - 9 } & \multicolumn{3}{|c|}{ Irrigation intervals } & \multicolumn{2}{|c|}{ Fertilizer. levels } & \multicolumn{2}{l|}{$\begin{array}{l}\text { Planting } \\
\text { methods }\end{array}$} \\
\cline { 2 - 9 } & $\mathrm{I} 14$ & $\mathrm{I} 21$ & $\mathrm{I} 28$ & $\mathrm{~F} 1$ & $\mathrm{~F} 2$ & $\mathrm{~F} 3$ & $\mathrm{R}$ & $2 \mathrm{R}$ \\
\hline Okra & 54.83 & 51.78 & 46.68 & 47.65 & 51.75 & 55.11 & 54.44 & 48.54 \\
\hline Garlic & 47.24 & 42.33 & 37.71 & 40.34 & 42.39 & 44.76 & 45.38 & 39.62 \\
\hline
\end{tabular}


Data in table ( 3) show that the highest irrigation water quantity of okra and garlic crops were 63.4 and $53.59 \mathrm{~cm}$ due to interaction between irrigation interval 14 days, fertilizer level $60 \mathrm{uN} / \mathrm{fed}$ and panting on one row ,while lowest values were 40.53 and $34.13 \mathrm{~cm}$ due to interaction between irrigation every 28 days and fertilizer $40 \mathrm{uN} /$ fed and planting on two rows

Table (3 ) : Effect of interaction between irrigation intervals, fertilizer levels and planting methods on irrigation water quantity of okra and garlic crops.

\begin{tabular}{|c|c|l|l|l|l|l|l|l|l|}
\hline \multicolumn{9}{|c|}{} & \multicolumn{4}{|l|}{ Water applied cm okra } & \multicolumn{4}{|c|}{ Water applied garlic cm } \\
\hline \multicolumn{2}{|c|}{ Treatments } & I14 & I21 & I28 & M & I14 & I21 & I28 & M \\
\hline F1 & R & 56.33 & 50.70 & 45.25 & 50.76 & 47.35 & 42.62 & 38.78 & 42.92 \\
\hline & 2R & 48.80 & 44.09 & 40.53 & 44.47 & 41.67 & 37.50 & 34.13 & 37.77 \\
\hline & M & 52.57 & 47.40 & 42.89 & 47.65 & 44.51 & 40.06 & 36.46 & 40.34 \\
\hline F2 & R & 59.80 & 54.93 & 49.32 & 54.68 & 50.37 & 45.33 & 40.30 & 45.33 \\
\hline & 2R & 52.00 & 47.63 & 44.72 & 48.82 & 43.82 & 39.44 & 35.06 & 39.44 \\
\hline & M & 55.90 & 52.33 & 47.02 & 51.75 & 47.10 & 42.39 & 37.68 & 42.39 \\
\hline F3 & R & 63.41 & 58.00 & 52.24 & 57.88 & 53.59 & 47.7 & 42.34 & 47.88 \\
\hline & 2R & 55.80 & 53.20 & 48.00 & 52.33 & 46.62 & 41.49 & 36.83 & 41.65 \\
\hline & M & 56.03 & 55.60 & 50.12 & 55.11 & 50.11 & 44.54 & 39.59 & 44.76 \\
\hline & & 54.83 & 51.78 & 46.68 & 51.50 & 47.24 & 42.33 & 37.71 & 42.50 \\
\hline
\end{tabular}

Interaction between irrigation intervals and fertilizer levels for okra and garlic crops are shown in Fig, 1. for all irrigation intervals, increasing fertilizer levels increase the irrigation water quantity for okra and garlic crops.

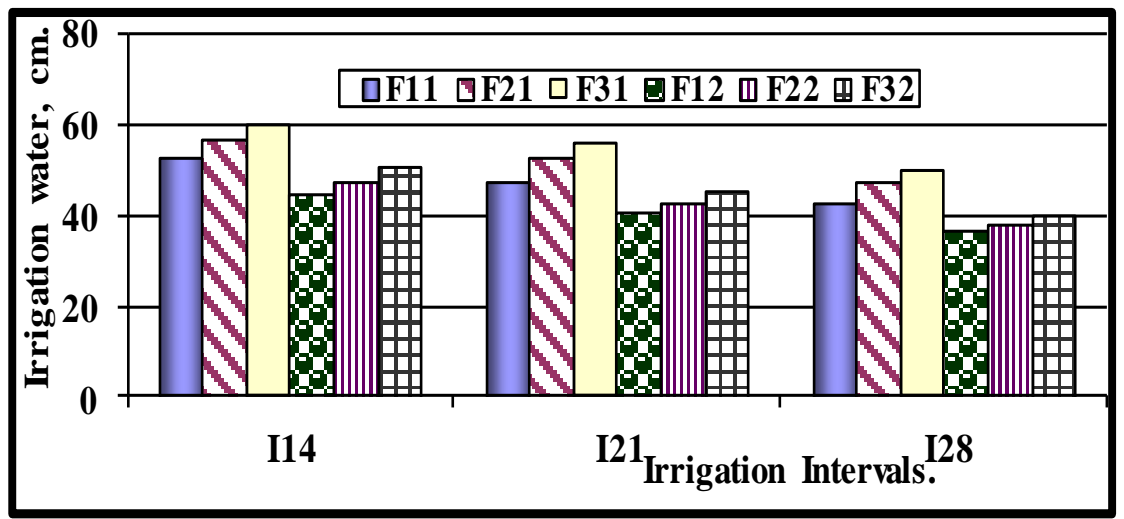

Fig. 1. Interaction between irrigation intervals and fertilizer levels on irrigation water quantity of okra \&Garlic crops. 
Nerveless interaction between irrigation intervals and planting methods saved irrigation water quantity as shown in fig. 2 .

The same trend by interaction between fertilizer levels and planting methods, under all fertilizer levels, planting on two rows saved irrigation water for okra and garlic crops ( Fig. 3.) .

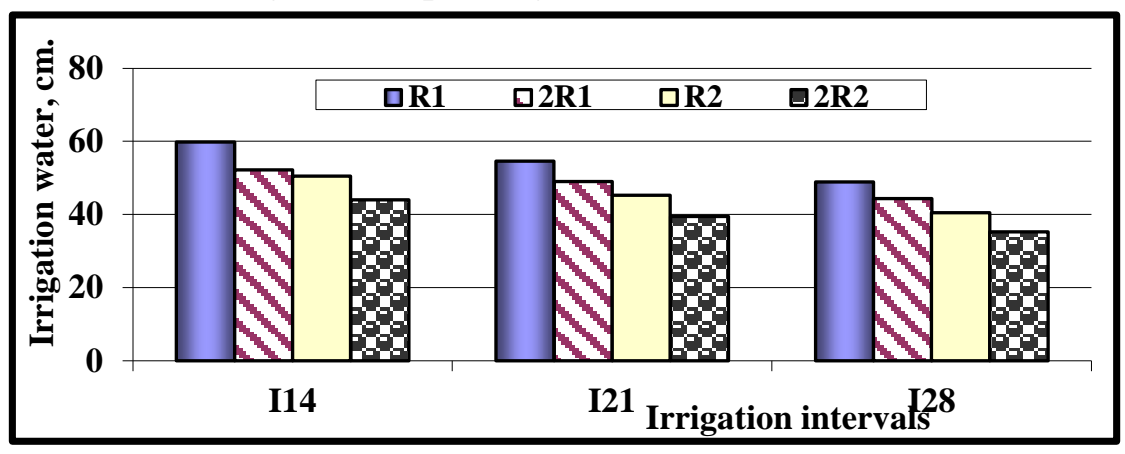

Fig. 2. Interaction between irrigation intervals and planting methods on irrigation water quantity $(\mathrm{cm})$ of okra \&Garlic crops.

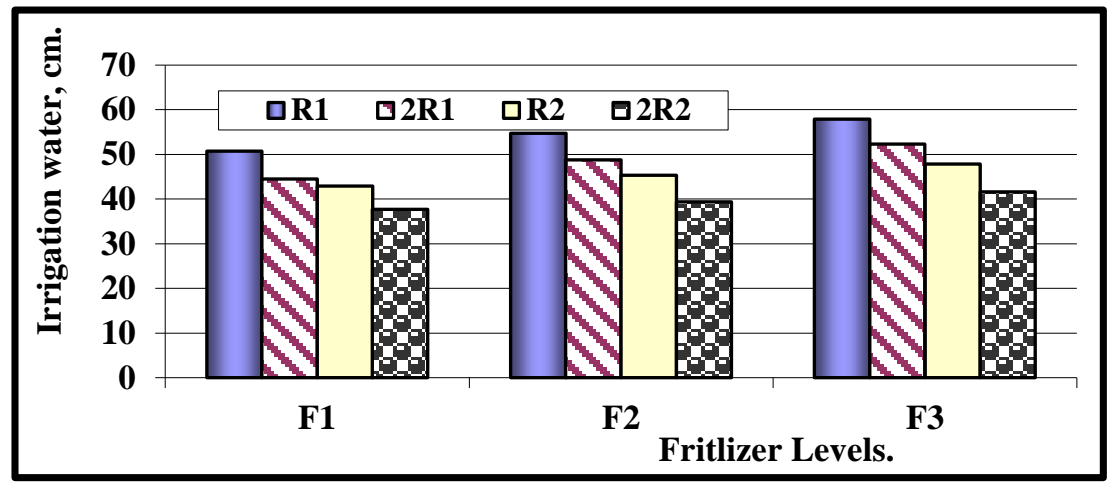

Fig.3. Interaction between fertilizer levels and planting methods on irrigation water quantity $(\mathrm{cm})$ of okra \&Garlic crops.

\section{Yield of crops ( ton /fed.)}

Yield of okra and garlic crops affected by irrigation intervals, fertilizer levels, planting methods and interaction between them ,

Data in table (4) show that increasing the irrigation intervals decrease yield of okra by 6.00 and $9.8 \%$ for irrigation every 21 and 28 days compared with irrigation every 14 days .Nerveless increasing irrigation intervals of garlic, yield increase with 8.73 and $18.59 \%$ for irrigation every 21 and 28 days compered by irrigation every 14 days. 
Also data show that increasing fertilizer levels from 40 to 50 and $60 \mathrm{uN} /$ fed , increase the yield by 9.06 and $18.53 \%$ for okra crop. Meanwhile, for garlic the increasing percent were 6.40 and $7.73 \%$ resp.

Effect of planting methods on yield of okra and garlic crops show in table ( 4 ) where yield increase by 6.36 and $11.05 \%$ by planting two rows for okra and garlic comparing with the planting on one row.

Table (4) : Effect of irrigation intervals, fertilizer levels , planting methods on yield of okra and garlic crops .

\begin{tabular}{|l|l|l|l|l|l|l|l|l|}
\hline & \multicolumn{9}{c|}{ Yield ton /fed. } \\
\hline & \multicolumn{3}{|c|}{ Irrigation intervals } & \multicolumn{3}{c|}{ Fertilizer levels } & \multicolumn{2}{|c|}{$\begin{array}{l}\text { Planting } \\
\text { methods }\end{array}$} \\
\hline & I14 & I21 & I28 & F1 & F2 & F3 & R & $2 \mathrm{R}$ \\
\hline Okra & 5.311 & 5.01 & 4.837 & 4.544 & 4.956 & 5.386 & 4.809 & 5.115 \\
\hline Garlic & 6.599 & 7.175 & 7.826 & 6.908 & 7.350 & 7.442 & 6.794 & 7.545 \\
\hline
\end{tabular}

Data in table ( 5 ) show that, Yield of okra and garlic crops affected by interaction between irrigation intervals, fertilizer levels and planting methods. Interaction between irrigation every 14 days, fertilizer $60 \mathrm{uN} /$ fed and planting on two rows gave highest yield value of ( 5.854 ton / fed) of okra . Garlic gave highest yield value of( 8.096 ton/ fed) due to interaction between irrigation every 28 days, fertilizer $60 \mathrm{uN} / \mathrm{fed}$ and planting on two rows. This result may be due to plant received adequate irrigation water quantity, while lowest yield value of 4.080 ton/ fed of okra due to interaction between irrigation every 28 days, fertilizer $40 \mathrm{uN} /$ fed and planting on one row and 6.000 ton/fed for garlic crop due to interaction between irrigation every 14 days, fertilizer $40 \mathrm{uN} /$ fed and planting on one row. This result may be because plant received unsuitable irrigation water amount of okra and garlic crops . Irrigation every 28 days of okra the plant received little amount of irrigation so , negative effect of yield was happen , while garlic irrigation every14 days, a large amounts of irrigation water leads to excessive leaching of nitrate nitrogen and making most of it unavailable to the plants which lead to a negative effect of yield. 
Table ( 5 ): Effect of interaction between irrigation intervals, fertilizer levels and planting methods on yield ( ton / fed) Of okra and garlic crops.

\begin{tabular}{|c|c|c|c|c|c|c|c|c|c|}
\hline & & \multicolumn{4}{|c|}{ Yield (ton/ fed) of okra } & \multicolumn{4}{|c|}{ Yield (ton/ fed) of garlic } \\
\hline & & I14 & I21 & I28 & $\mathrm{M}$ & I14 & $\mathrm{I} 21$ & $\mathrm{I} 28$ & $\mathrm{M}$ \\
\hline F1 & $\mathrm{R}$ & 4.731 & 4.500 & 4.080 & 4.437 & 6.000 & 6.500 & 6.700 & 6.400 \\
\hline & $2 \mathrm{R}$ & 4.900 & 4.752 & 4.302 & 4.651 & 6.270 & 7.000 & 7.500 & 6.923 \\
\hline & $\mathrm{M}$ & 4.816 & 4.626 & 4.776 & 4.544 & 6.160 & 6.995 & 7.569 & 6.908 \\
\hline $\mathrm{F} 2$ & $\mathrm{R}$ & 4.966 & 4.836 & 4.531 & 4.778 & 6.223 & 6.963 & 7.170 & 6.785 \\
\hline & $2 \mathrm{R}$ & 5.400 & 5.150 & 4.850 & 5.133 & 7.187 & 7.500 & 8.327 & 7.671 \\
\hline & $\mathrm{M}$ & 5.183 & 4.993 & 4.691 & 4.956 & 6.754 & 7.184 & 7.813 & 7.250 \\
\hline F3 & $\mathrm{R}$ & 5.532 & 5.253 & 4.850 & 5212 & 6.600 & 7.425 & 7.570 & 7.198 \\
\hline & $2 \mathrm{R}$ & 5.854 & 5.590 & 5.237 & 5.560 & 7.455 & 8,047 & 8.622 & 8.041 \\
\hline & $\mathrm{M}$ & 5.693 & 5.422 & 5.044 & 5.386 & 6.884 & 7.346 & 8.096 & 7.442 \\
\hline $\mathrm{M}$ & & 5.231 & 5.01 & 4.837 & 4.962 & 6.599 & 7.175 & 7.826 & 7.200 \\
\hline
\end{tabular}

Data in Fig. 4. show the effect of interaction between irrigation intervals and Fertilizer levels on yield . Yield increase by increasing fertilizer levels with all irrigation intervals. Interaction of irrigation every 14 days with $60 \mathrm{uN} /$ fed gave highest yield value ( 5.693ton /fed) of okra, while the highest garlic yield value was (8.096ton fed) due to interaction between irrigation every 28 day and fertilizer $60 \mathrm{uN} / \mathrm{fed}$.

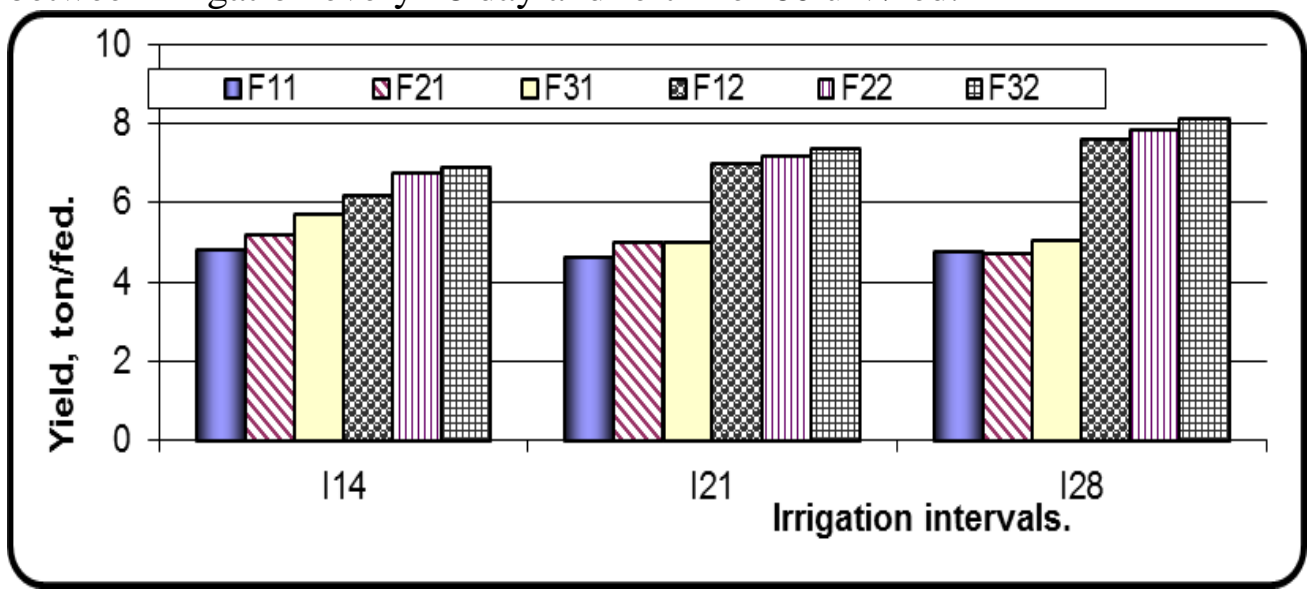

Fig. 4. Interaction between irrigation intervals and fertilize levels on yield ton/ fed of okra \& Garlic crops.

Combined application of high rates of water and $\mathrm{N}$ leads to excessive leaching of nitrate nitrogen, making most of it unavailable to the plants. Very few studies have been conducted to investigate the combined effect 
of irrigation method and scheduling on the yield, $\mathrm{N}$ use (based on $\mathrm{N}$ balance in the root zone) and $\mathrm{N}$ uptake (based on $\mathrm{N}$ content of plant material) of vegetable crops, Also yield increase due to interaction between irrigation intervals and planting methods .Result in fig. 5 show that ,highest value was $5.38 \mathrm{ton} /$ fed due to interaction between irrigation every 14 days okra yield and planting on two rows. While highest value for crop garlic was 8.150 ton / fed due to interaction between irrigation every 28 days and planting on two rows.

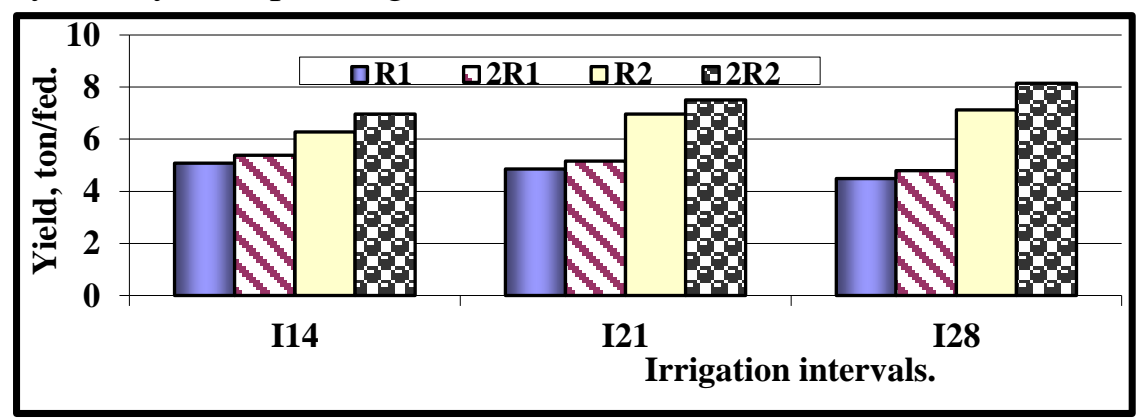

Fig. 5. Interaction between irrigation intervals and planting methods on yield ( ton /fed) of okra \&Garlic crops.

Yield of okra and garlic increase due to interaction between fertilizer levels and planting methods as shown in fig. 6 . Highest values of okra and garlic crops were 5.500 and 8.041 ton / fed, resp. due to interaction of fertilizer $60 \mathrm{uN} /$ fed and planting on two rows .

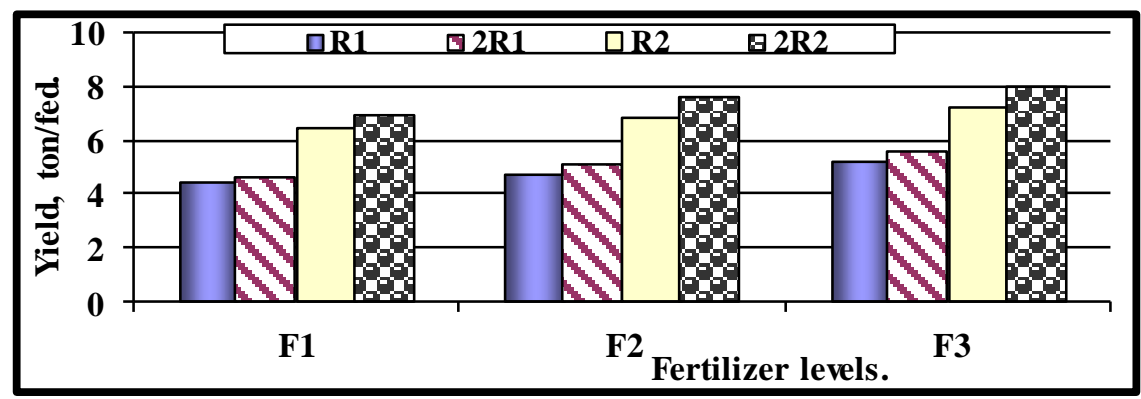

Fig. 6. Interaction between fertilize levels and planting methods on yield ( ton/ fed ) of okra \&Garlic crops.

\section{Water use efficiency ( WUE )}

water use efficiency affected by irrigation intervals, fertilizer levels , planting methods and interaction between them . 
Data in table (6 ) show that, water use efficiency $\left(\mathrm{kg} / \mathrm{m}^{3}\right)$ affected by irrigation intervals in okra crop where increasing irrigation intervals decrease WUE by about 6.30 and $17.67 \%$ increasing irrigation intervals to 21 and 28 days compered by irrigation every 14 days. This data was due to negative effect of little irrigation water on yield and WUE of okra crop. While garlic crop increase irrigation intervals increase WUE by 13.3 and $16.53 \%$ by irrigation every 21 and 28 days compered by irrigation every 14 days this data due to plant received adequate amount of irrigation water every 28 days case positive effect on yield and WUE of garlic crop.

Data in table (6) show effect of fertilizer levels on water use efficiency (WUE) . Increasing fertilizer levels, WUE increased by 3.06, 4.37, 2.47 and $3.73 \%$ under 50 and $60 \mathrm{uN} /$ fed compared to $40 \mathrm{uN} /$ fed for okra and garlic, respectively .

The same trend in planting methods has happen .Planting on WUE two rows of increasing percent were 17.59 and $25.67 \%$ of okra and garlic crops ,resp.

Table (6) : Effect of irrigation intervals, fertilizer levels and planting methods on WUE $\left(\mathrm{kg} / \mathrm{m}^{3}\right.$ of okra and garlic crops .

\begin{tabular}{|c|c|c|c|c|c|c|c|c|}
\hline \multicolumn{9}{|c|}{ WUE kg/m } \\
\hline crops & \multicolumn{3}{|c|}{ Irrigation intervals } & \multicolumn{2}{c|}{ Fertilizer levels } & \multicolumn{2}{c|}{$\begin{array}{c}\text { Planting } \\
\text { methods }\end{array}$} \\
\cline { 2 - 9 } & I14 & I21 & I28 & F1 & F2 & F3 & R & $2 \mathrm{R}$ \\
\hline Okra & 2.53 & 2.38 & 2.15 & 2.29 & 2.36 & 2.39 & 2.16 & 2.54 \\
\hline Garlic & 3.69 & 4.177 & 4.300 & 3.969 & 4.067 & 4.117 & 3.70 & 4.65 \\
\hline
\end{tabular}

Table ( 7 ) show that, water use efficiency of okra and garlic crops affected by interaction between irrigation intervals, fertilizer levels and planting methods. WUE was $2.74 \mathrm{~kg} / \mathrm{m}^{3}$ due to interaction irrigation every 14 day, fertilizer $60 \mathrm{uN} /$ fed and planting two rows of okra crop, while value was $4.95 \mathrm{~kg} / \mathrm{m}^{3}$ due to interaction irrigation every 28 days, fertilizer $60 \mathrm{uN} /$ fed and planting on two rows of garlic crop. This result was due to positive effect of irrigation every 14days for okra and 28 days for garlic with fertilizer $60 \mathrm{uN} /$ fed and plant two rows on yield and WUE. 
Table( 7 ): Effect of interaction between irrigation intervals, fertilizer levels and planting methods on WUE $\left(\mathrm{kg} / \mathrm{m}^{3}\right)$ Of okra and garlic crops.

\begin{tabular}{|l|l|c|c|c|c|c|c|c|c|}
\hline & & \multicolumn{4}{|c|}{ WUE okra $\mathrm{kg} / \mathrm{m}^{3}$} & \multicolumn{3}{|c|}{ WUE garlic $\mathrm{kg} / \mathrm{m}^{3}$} & \\
\hline & & $\mathrm{I} 14$ & $\mathrm{I} 21$ & $\mathrm{I} 28$ & $\mathrm{M}$ & $\mathrm{I} 14$ & $\mathrm{I} 21$ & $\mathrm{I} 28$ & $\mathrm{M}$ \\
\hline F1 & $\mathrm{R}$ & 2.22 & 2.15 & 1.90 & 2.09 & 3.27 & 3.68 & 3.74 & 3.563 \\
\hline & 2R & 2.65 & 2.53 & 2.32 & 2.50 & 4.00 & 4.37 & 4.76 & 4.377 \\
\hline & $\mathrm{M}$ & 2.44 & 2.34 & 2.11 & 2.29 & 3.66 & 4.03 & 4.25 & 3.969 \\
\hline F2 & $\mathrm{R}$ & 2.40 & 2.19 & 1.93 & 2.17 & 3.29 & 3.70 & 3.77 & 3.587 \\
\hline & 2R & 2.70 & 2.58 & 2.36 & 2.55 & 4.08 & 4.75 & 4.78 & 4.537 \\
\hline & $\mathrm{M}$ & 2.55 & 2.39 & 2.15 & 2.36 & 3.69 & 4.23 & 4.28 & 4.067 \\
\hline F3 & $\mathrm{R}$ & 2.46 & 2.21 & 1.97 & 2.21 & 3.30 & 3.71 & 3.78 & 3.597 \\
\hline & 2R & 2.74 & 2.60 & 2.38 & 2.57 & 4.11 & 4.82 & 4.95 & 4.627 \\
\hline & $\mathrm{M}$ & 2.60 & 2.41 & 2.18 & 2.39 & 3.71 & 4.27 & 4.37 & 4.117 \\
\hline M & & 2.53 & 2.38 & 2.15 & 2.35 & 3.69 & 4.177 & 4.30 & 4.05 \\
\hline
\end{tabular}

Water use efficiency affected by interaction of irrigation intervals and fertilizer levels as show on in fig. 7. Increasing fertilizer levels with all irrigation intervals lead to increase WUE in both crops. Irrigation every 14 days, fertilizer of $60 \mathrm{uN} /$ fed and planting on two rows gave the highest Water use efficiency value $\left(2.6 \mathrm{~kg} / \mathrm{m}^{3}\right)$ of okra crop. While the highest value for garlic was $4.37 \mathrm{~kg} / \mathrm{m}^{3}$ due to interaction irrigation every 28 day and $60 \mathrm{uN} / \mathrm{fed}$.

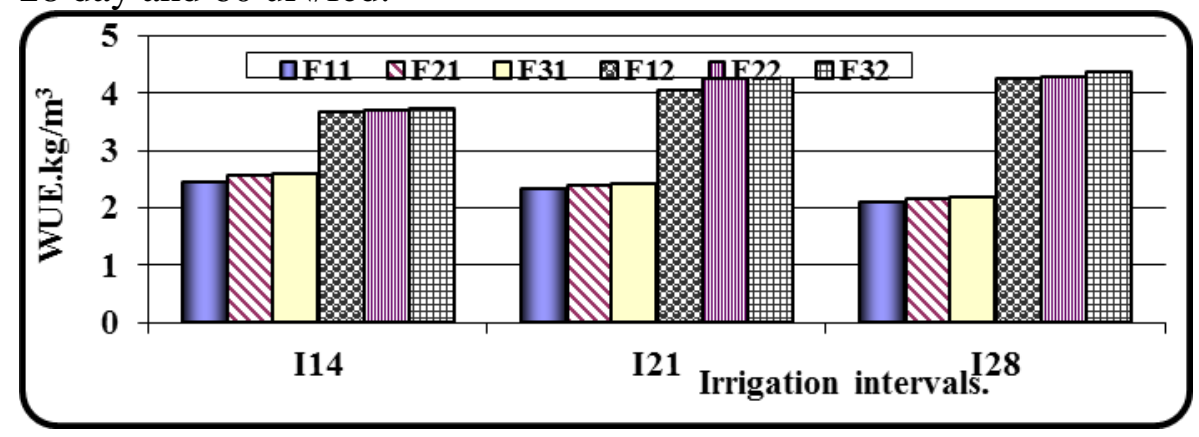

Fig. 7. Interaction between irrigation intervals and fertilizer levels on WUE $\left(\mathrm{kg} / \mathrm{m}^{3}\right)$ of okra \&Garlic crops.

Also, fig. 8. Show the interaction between irrigation intervals and planting methods .Interaction between irrigation every 14 days and plant two rows lead to highest value of WUE for okra $\left(2.70 \mathrm{~kg} /{ }^{3}\right)$. While interaction between irrigation every 28 days and planting on two row gave the highest value $4.83 \mathrm{~kg} / \mathrm{m}^{3}$ of WUE, for garlic. 


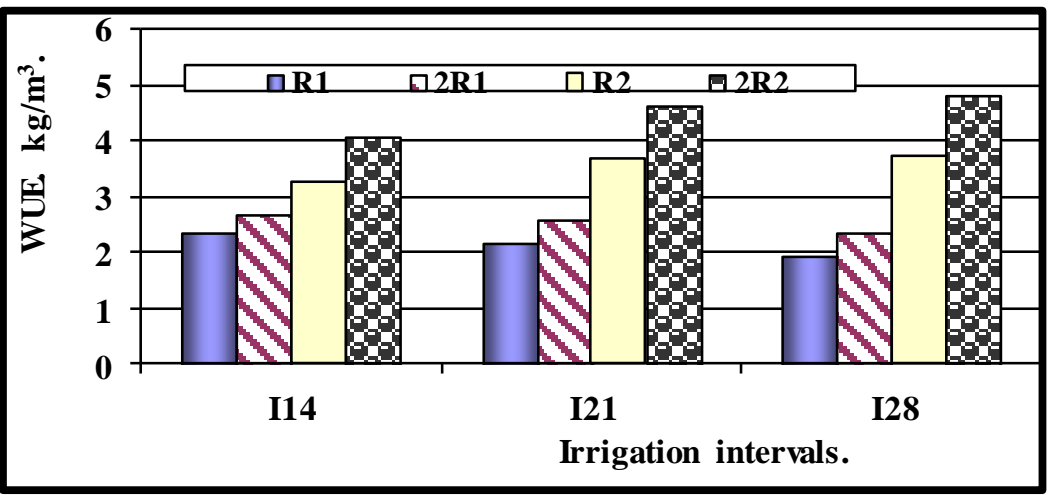

Fig. 8. Interaction between irrigation intervals and planting methods on WUE $\left(\mathrm{kg} / \mathrm{m}^{3)}\right.$ of okra \&Garlic crops.

Also the same trend in fig. 9, due to interaction between fertilizer levels and planting methods of okra and garlic crops. Data show the highest values were $2.57 \mathrm{~kg} / \mathrm{m}^{3}$ and $4.82 \mathrm{~kg} / \mathrm{m}^{3}$ due to interaction both fertilizers $60 \mathrm{uN} /$ fed and planting two rows in okra and garlic crops.

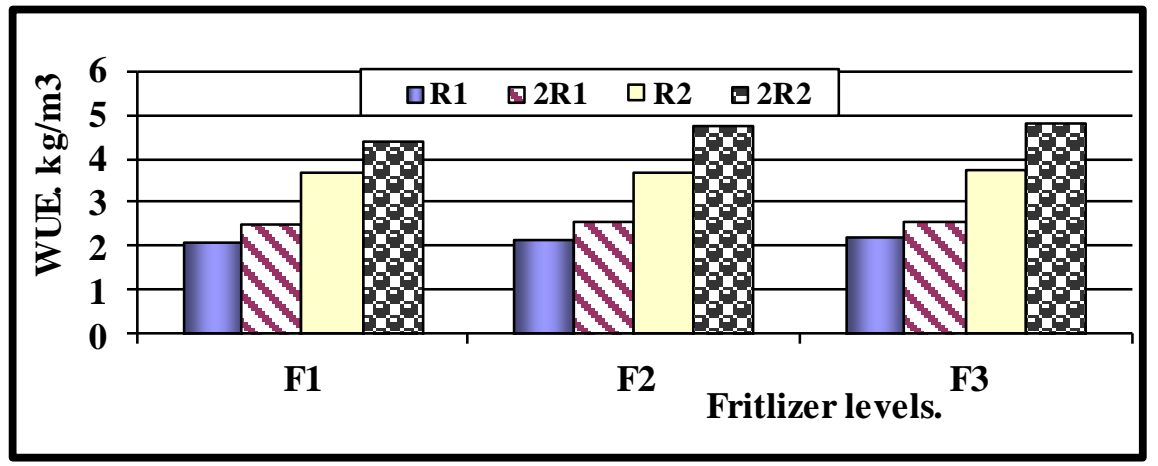

Fig. 9. Interaction between fertilize levels and planting methods on WUE $\left(\mathrm{kg} / \mathrm{m}^{3}\right)$ of okra \&Garlic crops.

\section{CONCLUSIONS}

The main results in the present work can be summarized in the following points.

1- Select suitable irrigation intervals to summer and winter crops.

2- When irrigation intervals increase, irrigation water quantity decrease in both okra and garlic crops.

3- Irrigation water quantity increase by increasing the fertilizer levels.

4- Planting on two rows save irrigation water quantity. 
5- Increasing irrigation intervals decrease yield of okra, but increase the garlic yield.

6- Increasing fertilizer levels, the water use efficiency increase for okra and garlic crops.

\section{REFERENCES}

Ali, G.F, Abolfazl, N. and Ali, E.N. (2010) Water use efficiency and yield of garlic responses to the irrigation system, -row spacing and nitrogen fertilization. Journal: Food, Agriculture and Environment (JFAE), Vol. 8, Issue 2, p.344-346..

Ahmed,H.G.,M.D.Magaji,A.I.Yakutu,L.AliyuandA. Singh( 2007). Response of Garlic (Allium sativum L.) To Irrigation Interval and clove Size in Semi-Arid,Nigeria. J.of Plant Sci.,2:202-208.

Buwalda, J.G.( 1987) Nitrogen nutrition of garlic (Allium satium L.) under irrigation. Crop Growth Dev. Sci. Hortic., 29: 55-68.

Hanson ,B., D. May, R. Voss,M. Cantwelland R. Rice( 2003). Response of garlic to irrigation water.Agric.WaterManag.Vol. 58, Issue 1, PP 29-43

Home,P.G. ,R.K. Panda and S. Kar( 2002) Effect of method and scheduling of irrigation on water and nitrogen use efficiencies of Okra (AbelmoschusesculentusAgric.WaterManag.Vol. 55, Issue 2, PP 159- 170.

Hanelt, P. (1990) Taxonomy, Evolution and History of Alliums. In:Onions and other Vegetables, Brewster,J.L.(Ed.).CRC Press Inc,Boca Raton,pp:11.

FAO ( 2001) Food and Agricultural Organization Rome: The Origin and Distribution of Garlic. USDA Agric. Res.Unit, USA.,pp: 98-108.

Mikko, S.,(2000) Effect of nitrogen, phosphorus and irrigation interval on the growth and yield of garlic (Allium sativum L.). Ph.D.Thesis. Submitted to the Postgraduate School, Ahmadu Bello University, Zaria, Nigeria.

Rajasooriyar, L.,V. Mathavan, H.A. Dharmagunawardhane and V. Nandakumar( 2002). Groundwater quality in the Valigamam region of the Jaffna Peninsula, Sri Lanka. Geol. Soc. Londan, 193: 181197.

Simon, W.(2001) The Origin and Distribution of Garlic. USDA, Vegetable Crops Res. Unit, USA.,pp: 1-3. 
Thanavendan, G. and S. Jeyarani(2009) Biointensive management of okra fruit borers using braconid parasitoids (Braconidae: Hymenoptera). Tropical Agric. Res., 21: 39-50.

$$
\begin{aligned}
& \text { الملخص العربحى }
\end{aligned}
$$

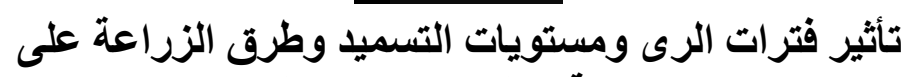

$$
\begin{aligned}
& \text { الانتاجية وكفاءة استخدام المياه } \\
& \text { * أمال فتوح الثرقاوى }
\end{aligned}
$$

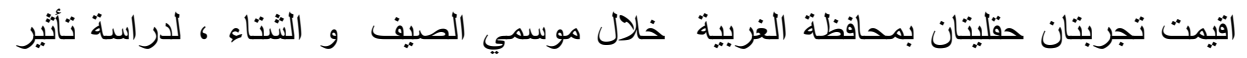

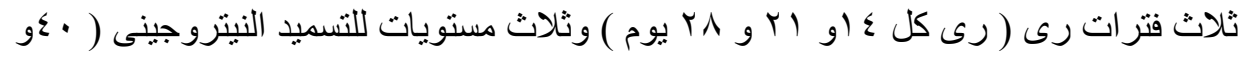

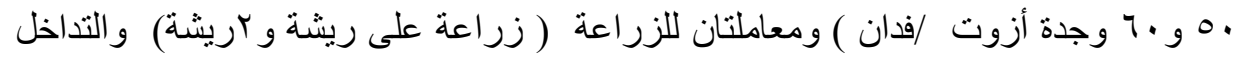

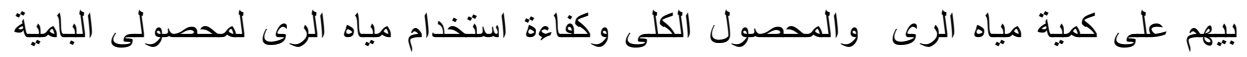
و الثوم وقد استخدم تصميم القطع المنشقة مرتين فى ثلاث مكرر الثيات ويمكن تلخيص الهم النتائج

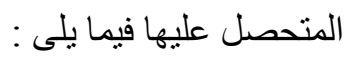

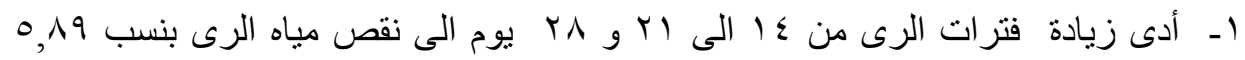

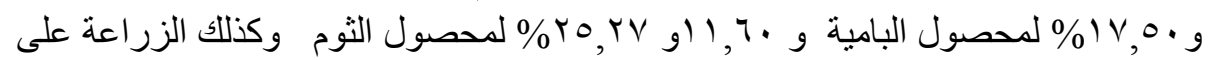

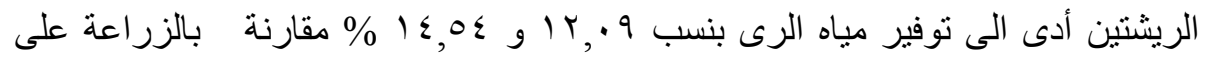

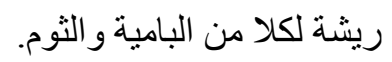

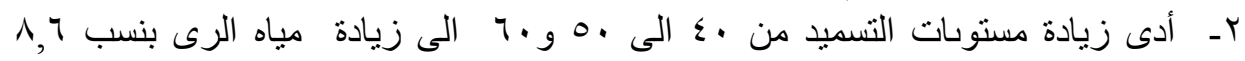

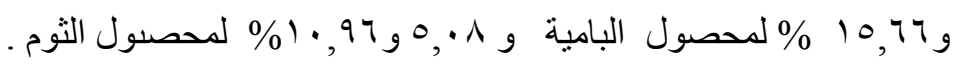

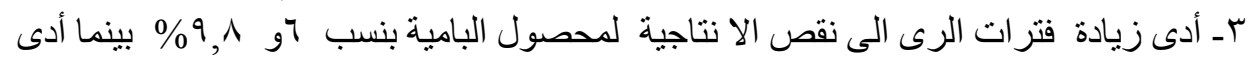

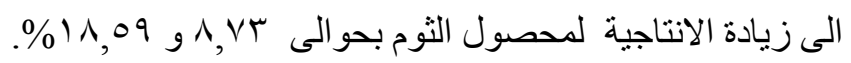

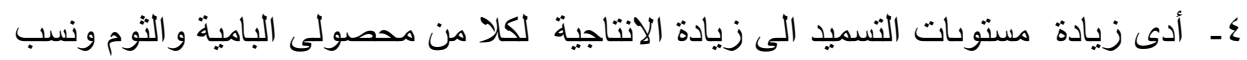

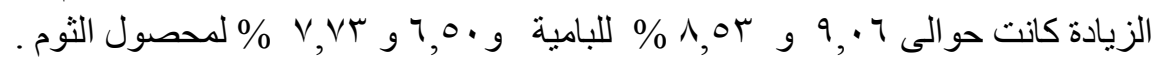

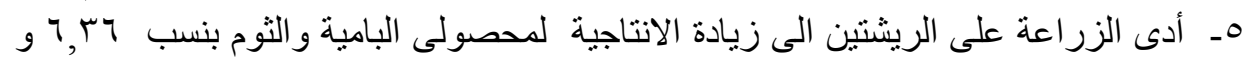

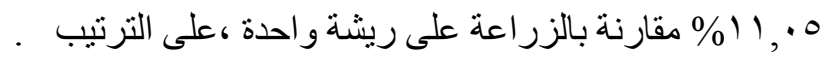

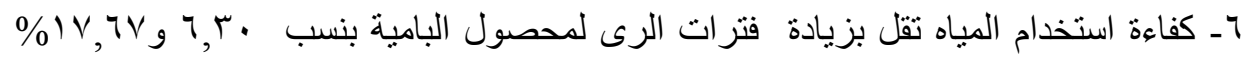

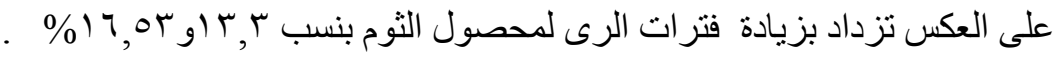

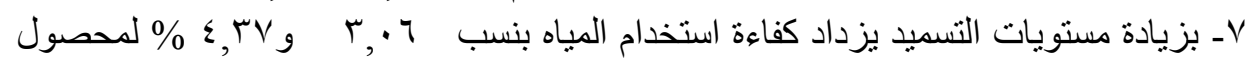

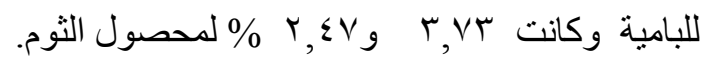

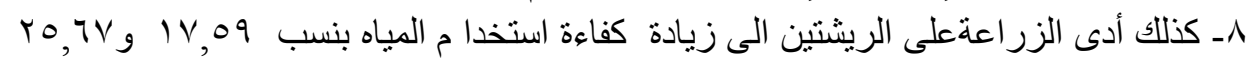

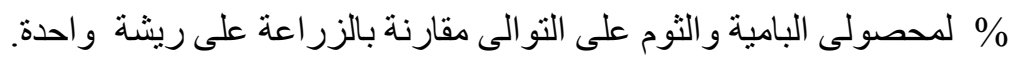

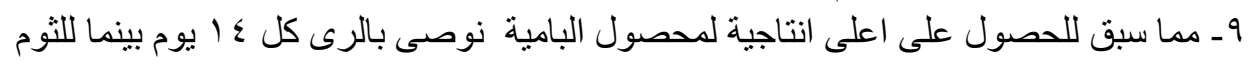

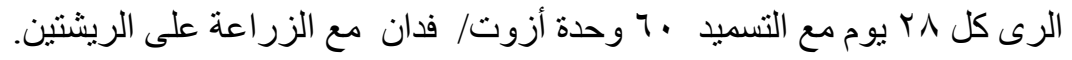

